\title{
構造用集成材の建方における施工人工数の研究 STUDY ON MAN-HOUR OF GLUED LAMINATED TIMBER'S ERECTION
}

\author{
田中 暁*, 松留 慎一郎** \\ Satoru TANAKA and Shinichiro MATSUDOME
}

\begin{abstract}
We surveyed 12 sites of erection with glued laminated timber. In this study we grasped the basic man-hour of erection and analyzed what items related to erection are suited to estimate the standard work time. On this report we introduce the idea of ZIGUMI-frame and classify the work of erection. Also we point out the suitable items and their standard work time in order to plan the schedule and man-hour of erection ahead of time.
\end{abstract}

Keyword: Glued laminated timber, Erection, Man-hour, Standard work, ZIGIMI-frame 構造用集成材, 建方, 施工人工数, 標隻作業, 地組架構体

\section{1.はじめに}

1987年の建築基準法改正に伴う関倸法令の改正により，構造用 集成材を用いた大規模木造建築物注急速に增加してきている。

しかし，一部の大手ゼネコンの内部資料を除き，構造用集成材 による大規模木造建築物の建方において, どの程度の施工人工数 がかかるのか, また，どのような工程計画を立てるのか，之の指 標となる各作業の労務歩掛りさえも十分に設定できていない。寒 際の建方にお汁る工程計画の立案は, 集成材メーカーの工事担当 者や実際に建方をおこなう作業者の経験に頼っており，体系的論 理的なものでないのが現状である。

搆造用集成材による大規模木造建築物の建方に関寸る研究 1 : : は，若干ではあるが散見できる。乞れらは施工管理と生産供給体 制に関する問題を取り上げており，現在の建方に扔汁る問題をア ンケート調查や実際の建方の例について総括的に述べているに留 まり，建方における施工人工数を詳細に調查したものミ゙ない。 工程計画の立案に用いることができるようなデー夕等は, 全く見 あたらないのが現状である。

そのような背景をふまえ, 本研究では, 建方の詳細な調查によ り收集したデータにもとづき, 総施工人工数のうちの標準作業に

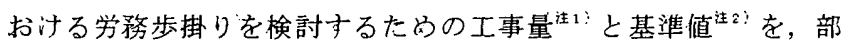

材別に示すことを目的としている。

\section{2. 調查概要}

\section{1. 調查対象}

アーチ式架構 3 事例, ポストアンドビーム式架構 6 事例, トラ ス式架構 3 事例の計12事例に対し下, 建方調査を実施した。各事 例の概要を表 1 に示寸。

\section{2 調查期間}

調查期間は平成 5 年10月から平成 8 年 6 月にわたっている。各 調查対象の建方の調查期間は, 表 1 にお汀る建方工事期間に相当 する。

\section{3 調查方法}

調查方法法建方現場におい下調査員が作業を観察し，あらかじ 的準備したコード表に基づき, 調查用祖に記入する方法をとった。 原則とし下調査員の観察により調査を実施したが，３事例にお汁 る母屋の吊り込み作業とこの他の吊り込み作業につい下だ讨は, 日報形式による調査にて補完した。日報の記入は，構造用集成材 メーカー所属で現場に常駐する建方専任の監督が抗こなった。併 せ下，確認の目的で，各作業の区切りごとに写真撮影をおこなっ た。

\footnotetext{
* 神奈川県立平塚高等職業技術校 技師・修士 (工学)
}

** 職業能力開発総合大学校建築工学科 助教授.工博
Engineer, Kanagawa Prefectural Hiratsuka Advanced Vocational Skill Training School, M. Eng.

Assoc. Prof., Dept. of Architectural Engineering, The Polytechnic University, Dr. Eng. 
記入内容は, 以下のとおりである。職種, 作業開始時間, 作業 終了時間, 対象部材, 本数, 位置, 作業内容

調蓇粒度は, 調㚗員の観測では分単位, 日報形式では30分単位 であった。

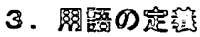

\section{1 作業の分類}

実際の作業を観察すると，建方を行う瞕種は，大工，䳏，重機， 及び，管理者に分穎できる。しかし，重機のオペレーターと，大 工や鴊等の作業者との作業量を，施工人工数として同等に評価す ることはできない。また，管理者も実際の建方作業をおこなうわ けではない。以下の分析では，重機及び管理者を含まずに，大工 と氙の作業に関するもののみを施工人工数として扱う。

建方現場に扔ける作業を, 大きく，「標準作業」，「標淮外作業」, 「隻備等」，「休み」に分類した。建方そのものの作業は，各部材の 「地組」，「吊り込み」，「取り付け」で構成されており，それらの作 業が順調に進行した場合を「標準作業」と定義した。寸法が合わな い等の理由でやり直す場合，才なわち，本来必要でない間違い作 業や取り外し作業等を「標隻外作業」と定義した。また，建方その ものの作業ではないもの, 例えば, 1 日の作業の準備, 後片づけ, 及び，荷下ろし等を「準備等」と定義した。分頻の定義を整理する と，以下のようになる。

(1)標準作業 ：誤作業等がなく順調に進行した作業

(2)標準外作業：誤作業による間違い作業や取り外し作業 例えば，地組作業や吊り込み作業の失敗等

(3)準備等：建方には直接関倸しない隻備等の作業 例えば，手待台，後片づけ，荷下ろし等

(4)休み : 昼休みや小休止

\section{2 地組架棬体}

また，実際の建方を観察すると，あるまとまった架構ごとにあ らかじめ地組をおこない，その地組された架構ごとに建方が実施 されている。地組された架構部分については，地組作業をおこな う架構の大きさとその数が，建方の施工人工数及び建方効率に最 も大きな影響を与えている。本研究では，地組作業をおこなう部 材に対して，「躯体を構成する主要な梁，柱，小屋組等を地組した
架構体」と定義し, 以下,「地組架槽体」と呼ぶ。地組架模体の地 組作業の際には，部材どうしの接合だけでなく，ベースプレート， 地組架榙体の吊り込み後に取り付けられる梁, 胴差, 柱, および, ブレース等の軸組材や母屋をうける金物もあらかじめ地組時に取 り付けられることも多い。その方が，地組架模体の吊り込み後に 架櫣の上でこれらの金物を取り付けるよりも，作業効率はよい。 しかし，これらの金物を地組作業の際に取り付けない亨例もみら れる。したがって, ベースプレートや梁, 胴差, 柱及びブレース 等の軸組材や母屋をうける金物については，地上で取り付ける場 合と架構上で取り付ける場合を想定して，地組架構体とは別に， 金物という部材項目を設定している。

\section{3 部材の分類}

標準作業において取り扱う部材を整理すると，以下のように分 頻できる。

(1)地組架構体：躯体を構成する主要な梁，柱，小屋組等を地組 した架構体

(2)軸組材 : 梁, 胴差, 柱, ブレース

(3)母屋 : 母屋

(4)金物 : ベースプレート，軸組材，母屋等を受汁る金物 (5)之の他：土台や应等の 2 次部材

以上の内容を整理すると，図1のように分頻される。また，施 工人工数を分析する際には，建築面積や材穦などの項目で割って 比較検討寸るのが一般的である。本研究では，「比較検討する際 に施工人工数を除するための，建筑面䅡や材積等の項目」を「工 事量」，「施工人工数を工事量の数值で除して，比較検討できる ように変換した数值」を「生産原単位」と定義する。

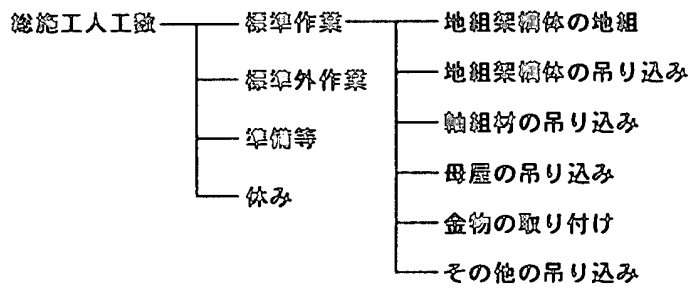

图 1 作签内容の分熲

焉 1 調疽対象の概要

\begin{tabular}{|c|c|c|c|c|c|c|c|c|c|c|}
\hline 名称 & 所在地 & 用途 & 階欵 & 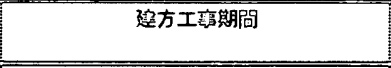 & 絮維方式 & 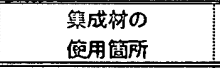 & $\begin{array}{l}\text { 籍成树 } \\
\text { の㓻合 }\end{array}$ & 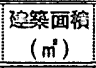 & 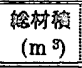 & $\begin{array}{c}t^{\prime}-\text { 敳 } \\
\text { (許) }\end{array}$ \\
\hline 事挒A & 北海道夕㖘郡 & フール & RC平军(叚根のみ木道) & H5.10.28 11.08 & アーチ & アーチ、小望 & $73 \%$ & 768 & 98 & 477 \\
\hline 弯峢B & 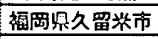 & 武殹婸 & 办造平屏 & H5.11.10 12.4 & アーチ & アーチ、小澹、同差、柱 & $99 \%$ & 680 & 57 & 282 \\
\hline 率挒C & 和歌山県龍拍田 & 体商媳 & 亦造平㞗 & H5.12.9 - 12.25 & アーチ & アーチ、小望 & $71 \%$ & 534 & 64 & 840 \\
\hline 衰挒D & 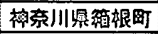 & 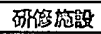 & 亦造平瓷 & H6.7.29 8.8 & ボ ストアンドピーム & 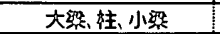 & $63 \%$ & 337 & 47 & 380 \\
\hline 亭列E & 秋田罚能代市 & 硕究所 & RC2 階亦造 1 倠 & H6.8.17 7.27.9.7 $\sim 9.21$ & 术 자アンドピーム & 大然、往、小梁 & $100 \%$ & 686 & 81 & 357 \\
\hline 毫挒 F & 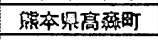 & 姣舎 & 东道 2 階 & H6.11.21 11.28 & 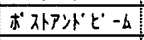 & 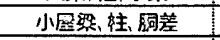 & $49 \%$ & 203 & 70 & 867 \\
\hline 事例 G & 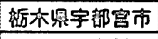 & 侮育能 & RC平资(屋根のみ东道) & $\mathrm{H} 7.7 .17 \sim 7.28,8.7$ & 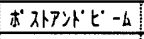 & 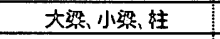 & $81 \%$ & 495 & 59 & 960 \\
\hline 裹例 $\mathrm{H}$ & 长影梠栄村 & 公民㿟 & 奕造 2 階 & $\mathrm{H} 7.9 .8 \sim 10.5$ & 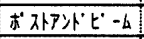 & 小星然，往、洞差、小澹 & $76 \%$ & 514 & 109 & 1331 \\
\hline 変挒 I & 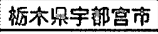 & 碄修摛設 & 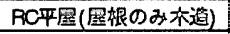 & $\mathrm{H} 7.10 .30 \sim 11.12$ & 求䄭アンドピーム & 大等，小䂐，柱 & $86 \%$ & 555 & 73 & 1081 \\
\hline 襄例J & 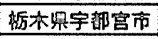 & 遊技施設 & 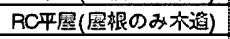 & $H 7.7 .5 \sim 7.17$ & トラス & トラス、小㴶プース & $100 \%$ & 398 & 48 & 259 \\
\hline 重列K & 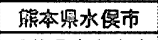 & 体育馆 & 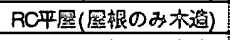 & $H 7.12 .25 \sim 12.29 . \mathrm{H8} .1 .8 \sim 1.13,1.16$ & トラス & トラス & $85 \%$ & 1024 & 84 & 437 \\
\hline 衰例L & 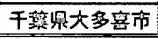 & 校舎 & RC2 階(䚄很のみ东通) & $\mathrm{H} 8.6 .18 \sim 6.29$ & トラス & トラス、小算 & $95 \%$ & 284 & 23 & 326 \\
\hline 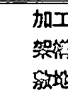 & 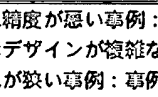 & 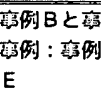 & と重例 $\mathrm{H}$ & 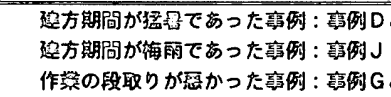 & $\begin{array}{l}\text { と夜挒 G } \\
\text { と市挒 I }\end{array}$ & & & & & \\
\hline
\end{tabular}




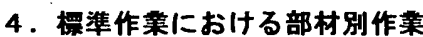

\section{1 分析の方針}

実際の作業を観察すると，接合方式がボルトであるか，ドリフ トピンであるか，在来の継手仕口であるかにより，施工人工数が 特に大きく異なる。したがって, 生産原単位に関寸る以下の分析 は，接合方式別におこなう。本研究では，調查对象12事例の接合 方式は，ボルト接合が10事例，ドリフトピン接合が 1 事例，在来 の継手仕口が 1 事例となっているため，ボルト接合を中心に分析 をおこなっている。

\section{2 地組架構体の地組作業}

地組作業を観察すると，地組する部材の移動と接合がその主な 作業となっている。したがって，地組架構体の地組作業には，地 組架構体の大きさと接合数が影響を与えると考えられる。ここで は，大きさをあらわす工事量として材樌注9)，また，接合数をあら

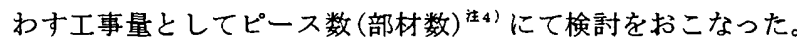

これらの工事量で生産原単位に変換した数值の比較を，図 2 に 示す。図2では，生産原単位に変換した数值のうちの最小值に対 して，他の事例の数值が何倍になっているか，その倍率をプロッ トし，それらを工事量ごとに示している。また，各事例は，それ ぞれ10体前後の地組架構体で構成されている。地組架構体に関す る施工人工数は, どの事例においても，最初の数体の作業がやや

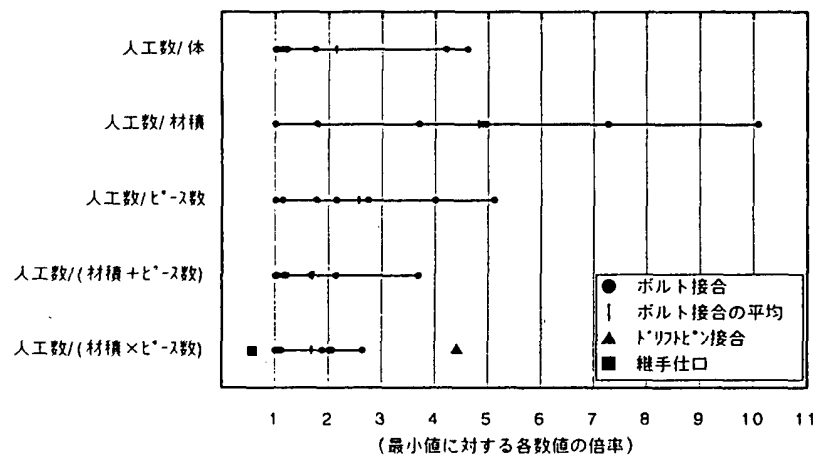

図 2 地組架構体の地組作業における生産原単位の比較

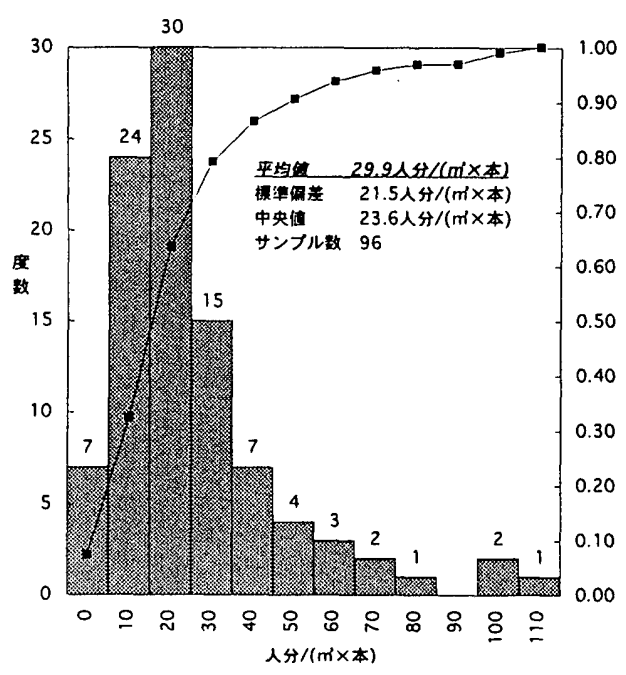

図 3 地組架構体の地組作業における施エ人工数/ (ピース数 $\times$ 村積)の度数分布図 (ボルト接合)
手間取るもののほぼ同じような数値を示していることが，文献3） にて分かっている。図 2 をみると，材積やピース数で単純に生産 原単位に変換した数值では, 最小值に対して最大値が約 5 倍及び 約10倍となっている。それに対して，材積とピース数の積（材積 $\times$

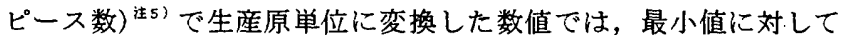
最大值が約2.5倍となっている。また，材積とピース数の和（材稙 +ピース数)で生産原単位に変換した数值では，最小值に対して最 大值が約 4 倍となっている。

どのような工事量や生産原単位を用いるか検討する場合，設計 時点で計画するという意味では設計図書等にて拾いやすい工事量 であること，また，建物，敷地，及び，作業者等の工事に関する 固有の条件は工事毎に個別に対応するとして，その前提となる数 値涤件によらずその生産原単位の分布がなるべくまとまってい る方が適切である。即ち, ここでの最小值に対して各数值の倍率 がなるべく小さくなっている工事量の方が適切であると考える。 したがって, 今回の調查対象の範囲内においては, 地組架構体の 地組作業では，材積とピース数の積 (材積 $\times$ ピース数)が労務歩措 かりを険討するための工事量としては適切であると言える。

ボルト接合の 7 事例に関して，材䄼とピース数の積(材積 $\times$ ピー ス数)で生産原単位に変換した数值の度数分布を，図 3 に示す。分 布は，正規分布に近似している。したがって，ボルト接合におけ

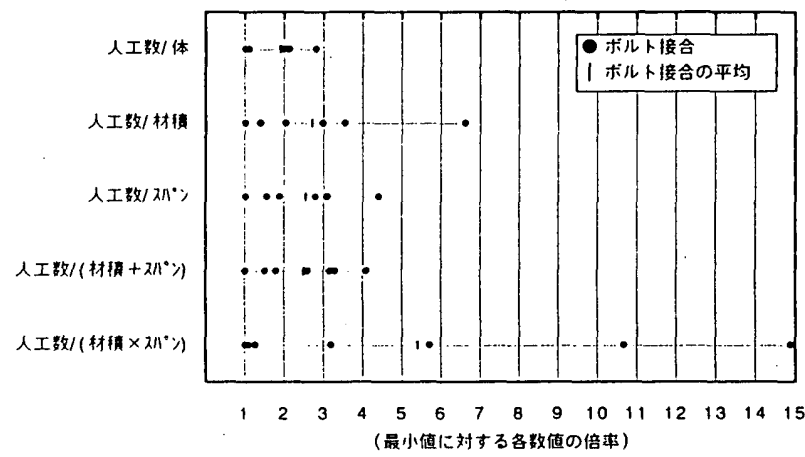

図 4 地組架構体の吊り込み作業における生産原単位の比較

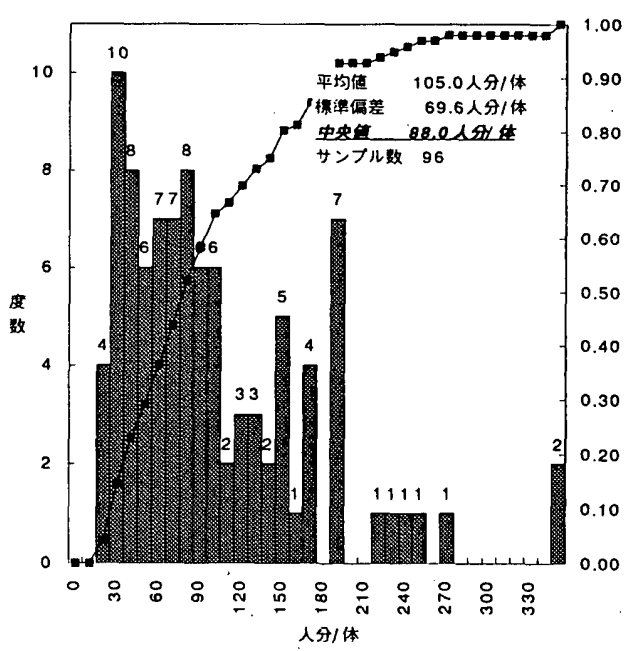

图5地組架構体 1 体あたりの吊り込み作業における 施エ人工数の度数分布図 (ボルト接合) 
る地組架樹体の地組作業では，平均值の 29.9 人分 $/\left(\mathrm{m}^{3} \times\right.$ 本 $)$ が基 淮值としてひとつの目安となろう。

\section{3 地組架模体の吊り込み作業}

建方で用いる重機は，最も重くスパンの大きい部材，才なわち， 地組架楼体の重さと, 重機と吊り元との距離によってその能力を 決める。したがって, 地組架構体の吊り込み作業では, どの地組 架槽体に対しても重機の能力が十分であるという意味で, 地組架 權体の重さがその施工人工数に影響を与える可能性は低いと言え る。ここでは, 工專量として材積とスパンにて，検討をおこなっ た。

これらの工率量で生産原単位に変換した数值の比較を, 図 $4^{\text {法6 }}$ に示す。ボルト接合に関しては，材皘で生産原単位に変換した数 值は約 7 倍の節囲，スパンや材積とスパンの和で生産原単位に変 換した数値は約 4 倍の節囲に分布している。一方で，これらの工 重量で生産原単位に変換しない数値, 寸なわち, 地組架满体 1 体 あたりの施工人工数は, 約 3 倍の鲫囲に分布している。したがっ て, 地組架椲体の吊り込み作業は, 工亭量で生産原単位に変換す るのではなく, 地組架構体 1 体あたりの施工人工数で検討するこ とが適切であると言える。

ボルト接合の 7 尌例に関して, 地組架構体 1 体あたりの吊り込 み作業における施工人工数の度数分布を，図 5 に示す。分布にか なりバラツキが見られ，正規分布であるとは言えない。ここでは，

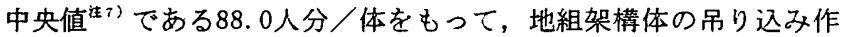
業の基準値とする。

\section{4 軸組材の吊り込み作業}

建方で用いる重機は，最も重くスパンの大きい部材，才なわち， 地組架櫣体の重さによってその能力が決定される。一方, 本研究 で定義した軸組材は，躯体を構成する部材の中でも比較的小さい ものが中心となっており, 重機の能力から考えても, 重さの工事 量に左右されにくい。したがって，軸組材の吊り込み作業には， 材樌やスパン等に関寸る工事量で生産原単位に変換せずに，1本 あたりの施工人工数で検討するするのが適切であると言える。

軸組材 1 本あたりの吊り込み作業にお汁る施工人工数の度数分

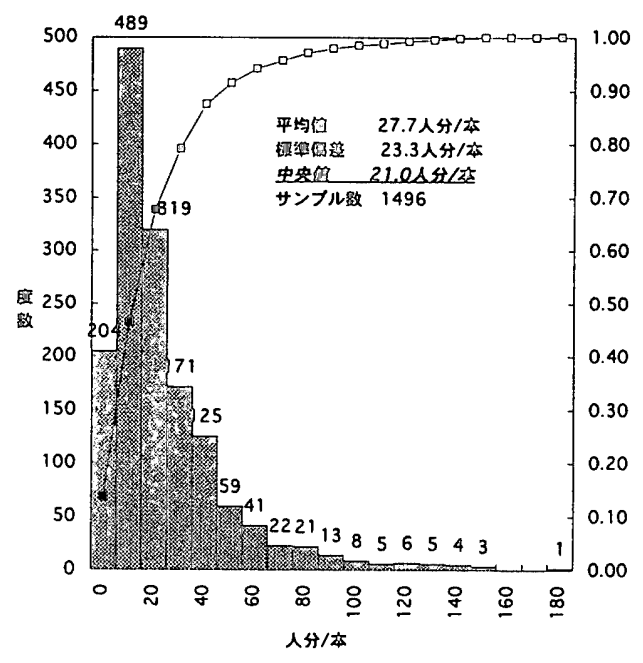

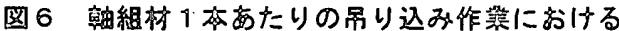
施工人工数の度数分务图 (ボルト络合)
布を, 図 6 に示す。度数分布は対数正規分布に近似している。こ こでは, 中央值 ${ }^{\text {注 }}{ }^{2}$ の 21.0 人分/本をもって, 軸組材 1 本あたりの 吊り込み作業における基準值とする。

\section{5 母屋の吊り込み作業}

母屋は，軸組材に比べて 1 本あたりの材䅡やスパンが小さい。 そのため, 吊り込み作業の方法は，地組架構体や軸組材のように 重機により1本づつ吊り込むのではなく, 内部足場や地組架構体 の架棈の上に重機でまとめて吊り上げてから，作業者が 1 本ごと に手作業により納めてゆく。

母屋の吊り込み作業における施工人工数について，材積とピー ス数で生産原単位に変換した数値の比較を，図７に示す。材䅡と ピース数で生産原単位に変換した数值のバラツキに大きな差は見 られず，どちらでも基淮值となりうる。ピース数あたりの平均值 は 12 人分/本，材欑あたりの平均值は 350 人分 $/ \mathrm{m}^{3}$ である。

\section{6 金物の取り付け作業}

「3．用語の定義」で前述したように，金物の取り付け方法に は，地上で地組架構体に取り付ける方法と架構の上で取り付ける 方法がある。前者の方が一般的であり，作業効率もよい。また， 地上で取り付汀る方法であっても，架構の上で取り付ける方法で あっても，余程重い金物でない限り重機を用いないで作業者が 1 個ごとに手作業で取り付けていく。事例Dで注すべての金物が架 構上で取り付汁られているが，他の事例ではほとんどの金物が地 上で取り付汁られている。

調査におい下，金物取り付讨作業の施工人工数と取り付けた金

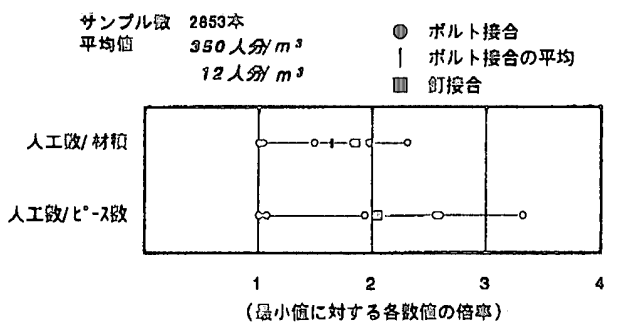

图 7 贯屋の吊り込み作菜における生産原单位の比皎

姲 2 金物の职り付け作蓄における施工人工数

\begin{tabular}{|c|c|c|c|c|c|}
\hline & $\begin{array}{l}\text { 人工纹 } \\
\text { 人分 }\end{array}$ & 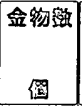 & 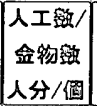 & 接合方式 & 职付埥所 \\
\hline FSOD & 5021 & 745 & 6.7 & ボルト & 呩㙘の上 \\
\hline 雨例G & 1799 & 800 & 2.2 & ポルト & 地上 \\
\hline 車倒I & 2853 & 970 & 2.9 & ボルト & 垉上 \\
\hline 平均值 & 2326 & 885 & 2.6 & 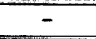 & 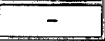 \\
\hline
\end{tabular}

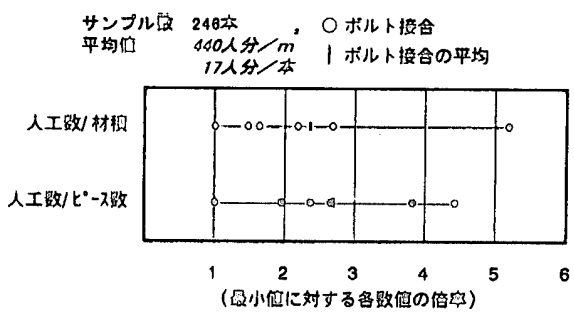

图 8 その他の吊り込み作篦における等産原単位の比皎 
物数を正確に把旺できた事例は 3 事例にすぎない。表 2 に，金物 の取り付け作業における施工人工数と金物数等を示寸。ここでは， 金物 1 個あたりの施工人工数を基準値としている。地上で取り付 け作業をおこなった事例 $G$ と事例 I では，金物 1 個あたりの施工 人工数が近い值を示しており，それらの平均值は2.6人分/個とな っている。一方, 架構の上で取り付けた事例Dでは 6.7 人分/個と なっており，地上にて取り付けた 2 事例の平均值の約 2.5 倍となっ ている。

4.7 その他の吊り込み作業

その他の部材の吊り込み作業の方法は，母屋と同様に重機によ りまとめて架構上や内部足場に吊り上げてから，作業者が 1 本ご とに手作業により納めてゆく。その他の吊り込み作業に扔汸施 工人工数を材積とピース数で生産原単位に変換しだ数值の比較を, 図 8 に示す。母屋の吊り込み作業と同様に，材積とピース数で生 原原単位に変換した数值のバラツキに大きな差は見られず，どち らでも基準値となりうる。ピース数あたりの平均值は 17 人分/本, 材積あたりの平均値は 440 人分 $/ \mathrm{m}^{3}$ である。注 9 )

4.83 つの階層にお打る生産原単位に変換した数值の比較

「3．用語の定義」で定義したように，標淮作業は，地組架構 体の地組・地組架構体の吊り込み・軸組材の吊り込み・屋の吊 り込み・金物の取り付け・その他の作業, という各作業の合計で あらわされる。これらの各作業をどのような工事量にて検討する のが適切であるかは既に述べたが，ここでは，総施工人工数，摽 準作業, 標準作業における部材別作業という3つの階層（レぶ ル）において生産原単位に変換した数值を比較検討する。

図 9 に,ボルト接合において, 総施工人工数, 標準作業, 標準 作業に㧍汀る部材別作業をそれぞれ生産原単位に変換した数值の 比較を示す。総施工人工数では最小值に対する最大值の比率が約 $5 \sim 9$ 倍, また, 標準作業では約 $4 \sim 10$ 倍であるのに対して, 部 材別作業では $2 \sim 3$ 倍に納まっている。これらの数值においては, その分布の狭い方が，労務歩挂りを険討寸るたらの参考値として は適切である。したがっ下，総施工人工数や標準作業で扱う数值 自体が部材別作業に比べて大きいことも考慮すると, 総施工人工
数や標準作業等の階層よりも，標準作業における部材別作業の階 層にて生産原単位に変換して分析する方が適切であると言える。

\section{5.まとめ}

本研究における分析結果をまとめると，以下のようになる。 (1)標準作業を, 地組架構体の地組作業, 地組架構体の吊り込み作 業, 軸組材の吊り込み作業, 母屋の吊り込み作業, 金物の取り付 け作業, 及び, その他のつり込み作業の $5 つ$ つ部材別作業に分類 した。

(2)工事量で生産原単位に変換する場合, 総施工人工数や標準作業 の階層（レベル）よりも，標準作業における部材別作業の階層に おいて生産原単位に変換して分析する方が適切である。

(3)各部材別作業における労務歩掛りを検討寸るための適切な工事 量とそれぞれの生産原単位における基準值は，以下のとおりであ る。なお, 地組架構体の地組作業と吊り込み作業, 軸組材の吊り 込み作業では，ボルト接合の場合について示してある。 地組架構体の地組作業：地組架構体96体の平均值 29.9 人分 $/\left(\mathrm{m}^{3} \times\right.$ 本) (地組架構体の 材皘 $\times$ ピース数 $)$

地組架構体の吊り込み作業: 地組架構体96体の中央值 88.0 人分/体 (地組架構体の数)

軸組材の吊り込々作業：軸組材1496本の中央值 21.0 人分/本 (軸組材の数)

母屋の吊り込み作業 : 母屋 2853 本の平均値 350 人分 $/ \mathrm{m}^{3}$ (母屋の材稙) 12 人分 /本 (母屋の数)

金物の取り付讨作業（地上）：地上取り付讨17 70 個の平均値 2.6 人分/個 (金物の数)

（架搆上）：架構上取り付讨 745 個の平均值 6. i人分/個 (金物の数)

その他の吊り込み作業：その他の部材246本の平均值 440 人分 $/ \mathrm{m}^{3}$ (その他の材積) 17 人分/本(之の他の数)

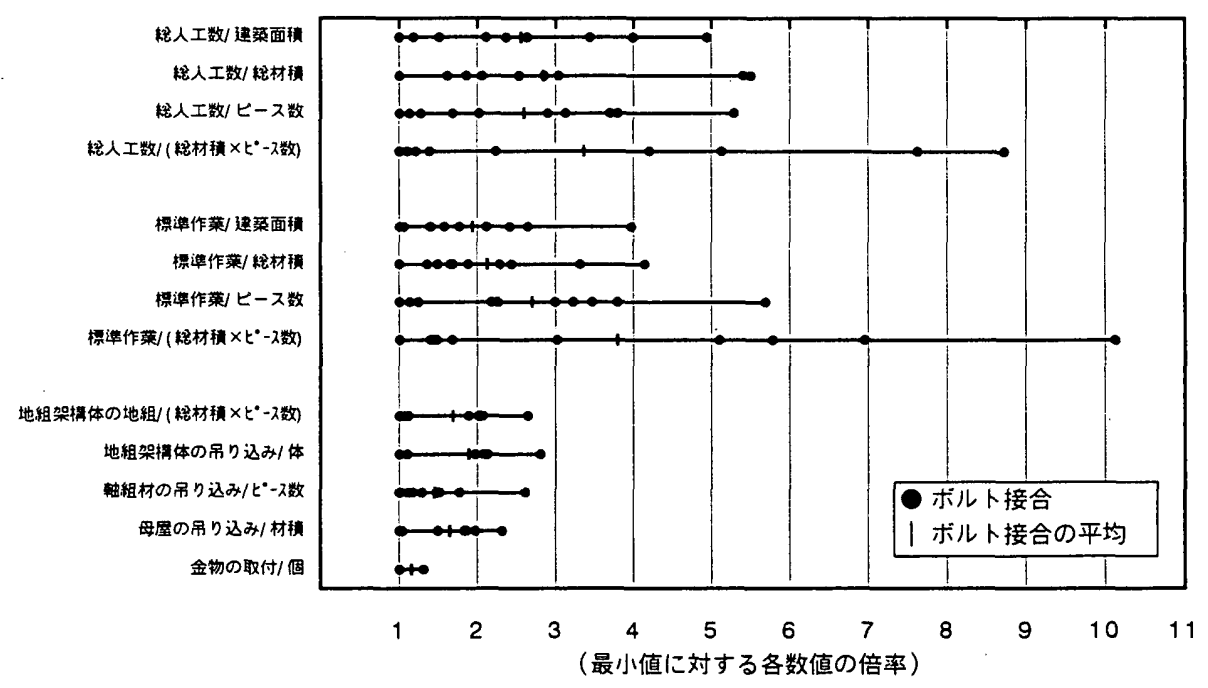

図 9 総施工人工数，標準作業，賒準作業における部材別作業内容の生産原単位の比較 


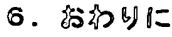

生産原単位には，接合方式以外にも作業者や管理者の技量，敨 地の条件, 加工精度, 架棬の複雑さ等が影響を与えている。本論 文では，ボルト接合方式に絞って分析を進めており，標準作業の 部材別作業に関して，生産原単位を示し，標準的な労務歩掛りの ための参考値とした。接合方式以外の施工人工数に影響を与える 条件 ${ }^{\text {汭) }}$ の分析は, 今後の課題とした。

\section{䇶碚}

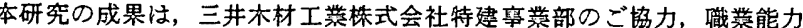
開発大学校超築工学科卒諭生原田貴透氏 (平成 5 年度), 児玉忍氏 (平成 6 年 度), 高野裕幸氏 (平成 7 年度), 松浦正典氏 (平成 8 年度), 及び, 山田大雅 氏(平成 9 年度)の努力に因るところが大きいことを記して，感爵いたしま す。

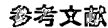

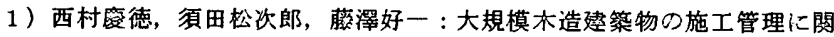
する諸問題, 日本建筑学会第 4 回「建筑生産と管理技術」シンポジウム諭 文集, pp. 23 26, 1988

2）西村度徳，須田松次郎，藤澤好一：大規模木造建筑物の生産供給体制 と施工管理に関する考察, 日本趣筑学会第 5 回「起筑生座と管理技術」シ ンポジウム䤅女集, pp. 61〜 64, 1989

3）松留慎一郎，田中暁：梅造用集成材を用いたアーチ式架梅とポストア ンドビーム式架梅の施工人工数に閵する調查報告，日本建筑学会技術報告 集第1号, pp. 269 274，1995. 12

4) 松留傎一郎：梅造用集成材を用いたアーチ式木造架荤の施工人工数に 関する調查研究，日本建筑学会第10回「建築生産と管理技術」シンポジウ 么諭文集, pp. 545 552, 1994

5) 田中獍, 松留慎一郎：椎造用集成材の施工人工数に関する研究 ポスト アンドビーム式木造架梅について，日本建筑学会第11回「建筑生産と管理 技術」シンポジウム論文集, pp. 275〜282, 1995

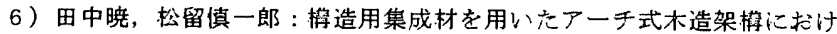
る施工人工数す試算に関する研究, 日本建築学会大会学術撞演梗概集 $\mathrm{E}$ 分 冊, pp. $587 \sim 588, \quad 1995$
7) 田中暁, 松留傎一郎：梅造用集成材の施工人工数汇関する研究长の 1

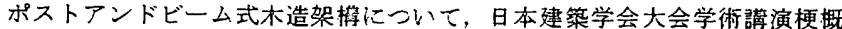
集E分冊, pp. 631 632, 1996

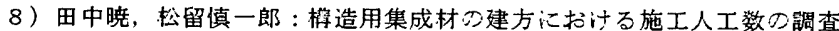

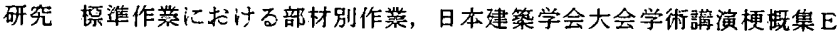
分冊, pp. 645 646, 1997

注

1）「3．用語の定義」に括计て工事量の定義を参昭のこと。

2）労務歩捍りを検討するたせの基準，むるいは，参考となる数值。

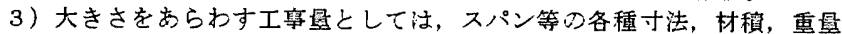
あるいは，それらの組み合わせ等，様々なもの方考光られる。設計時点で 必ず算出されるといらこと, しかも, 比翰的説明のつく分析結果を示して いるといら理由により，材稳を選定している。ここで报う地組架粠体の材

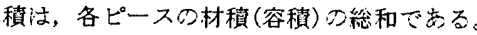

4）接合作業汇関しては，接合数に加えて，接合部に扔ける接合金物やボ ネ下の数等, 接合心複雑さ汃影響を与える。ピース数（部材数）引，接合 D数と必ずしも一致しふい。しかし，設計時点で必ず算出され下报いやす いということ，また，複数の部材により 12 所の接合部方棰成されている 場合变ど接合部の複䧴さをピース数だ代替だきるという理由で，ピース数 を選定している。なお，ピース数には，ボルト数流含まれない。

5）材稳とピース数の積は，大きさと接合数に関保しているということ以

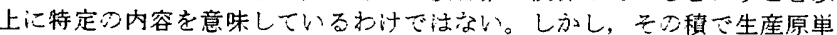
位に変換した数值において，事例ごとのバラツキが最も小さく夜こている。 そうから意味で,ここでは，工事量として採用している。

6)ここでも，各事例にお计る平均值をプロットしている。

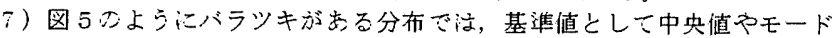

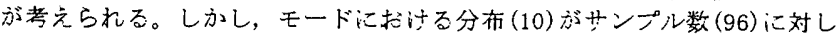

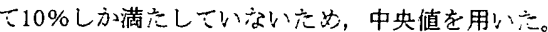

8）図6のように対数正規分布に近似している場合，基淮值としては中央 值を用いるのが一般的である。

9）母屋の吊り込み作業とその他のつり込み作業について注，12事例のう ち3章例が日報形式によるデータであるため，日報形式す調查精度である3 0分単位で集計をし，有效析数を 2 桁とした。

10）表1の下に，12重例において影響を与えた条件を示している。

（1998年 9 月 1 日原稿受理，1999年 1 月28日採用決定） 